\title{
WAYANG GOLEK \\ DARI SENI PERTUNJUKAN KE SENI KRIYA \\ (Studi tentang Perkembangan Fungsi Wayang Golek \\ di Kota Bogor)
}

\author{
Oleh Rosyadi \\ Balai Pelestarian Sejarah dan Nilai Tradisional Bandung \\ Jln. Cinambo No. 136 Ujungberung Bandung \\ Email: ochadroki@yahoo.com
}

\begin{abstract}
Abstrak
Wayang golek adalah suatu jenis seni pertunjukan tradisional yang telah menjadi bagian dari jati diri orang Sunda. Perkembangan dunia hiburan yang kini lebih didominasi oleh jenis-jenis kesenian modern, telah mengakibatkan semakin langkanya pertunjukan kesenian wayang golek dipergelarkan.

Dalam pada itu, perkembangan dunia pariwisata telah menciptakan karya baru bagi wayang golek, yaitu sebagai barang souvenir. Maka fungsi wayang golek pun berkembang dari seni pertunjukan menjadi seni kriya.
\end{abstract}

Kata Kunci: Wayang Golek, hiburan, seni kriya.

\begin{abstract}
Wayang golek is one of traditional entertaining art and it has become identity of Sundanese people. The growth of modern entertainmen, which more dominated by a modern art, it caused events of traditional art such as wayang golek is more dificult to find.

Mean while,growing of tourism industry has made a new change for wayang golek. In this case wayang golek has become a souvenier. So, there is a change of wayang golek function from entertaining art to be handycraft.
\end{abstract}

Keywords: puppet, entertainment, art, handycraft.

\section{A. Pendahuluan}

Salah satu kelebihan mahluk manusia dari jenis-jenis mahluk lainnya di muka bumi ini ialah di samping manusia dikaruniai akal fikiran, manusia juga dikaruniai rasa keindahan. Dalam kehidupan manusia, keindahan sangat erat kaitannya dengan urusan batin dan rasa. Kemampuan manusia dalam mengolah rasa, batin, dan akal pikiran, kemudian melahirkan kesenian, yang merupakan bagian penting dan tak terpisahkan dari kebudayaan manusia.

Kesenian sebagai subsistem kebudayaan, merupakan ungkapan krea-tifitas dari kebudayaan itu sendiri. Ia men- 
ciptakan, memberi peluang untuk bergerak, memelihara, menularkan, mengembangkan untuk kemudian menciptakan kebudayaan baru lagi (Koentjaraningrat, 1981/1982). Berkesenian adalah salah satu kebutuhan hidup manusia dalam bentuk pemenuhan kebutuhan akan rasa keindahan.

Dalam konteks kemasyarakatan, jenis-jenis kesenian tertentu memiliki kelompok-kelompok pendukung tertentu. Demikian pula kesenian bisa mempunyai fungsi yang berbeda di dalam kelompokkelompok manusia yang berbeda. Perubahan fungsi dan perubahan bentuk pada hasil-hasil karya seni, dengan demikian dapat pula disebabkan oleh dinamika masyarakat. Di sisi lain, tata masyarakat dan perubahannya turut pula menentukan arah perkembangan kesenian.

Sekalipun kesenian dicirikan dari keindahannya, tetapi kesenian tidak hanya dapat dikaji dari sudut penataan artistiknya saja yang akan menumbuhkan rasa kekaguman yang mendalam bagi para penikmatnya. .Dalam pandangan lain yang justru akan memberikan penjelasan lebih luas, kesenian juga dapat dilihat dari sudut pandang latar belakang kebudayaannya yang akan mampu mengungkap makna simbolik dari kesenian tersebut.

Seniman, di samping anak dari bangsanya, juga tidak terelakkan sebagai anak dari zamannya. Kini, zaman tengah dilanda proses modernisasi dan globalisasi yang seringkali diidentikkan dengan pemikiran-pemikiran dan peradaban barat. Dengan demikian setiap pemikiran barat yang dilontarkan melalui karya seni, turut merembet melalui seniman yang pada akhirnya disebarluaskan ke dalam lingkungan masyarakat luas.

Keberadaan kesenian-kesenian tradisional mulai tergeser dengan keberadaan kesenian-kesenian baru yang mewakili pemikiran-pemikiran barat.
Demikian pula fungsi dari kesenian tradisional mulai melemah. Padahal, bagi masyarakat pendukungnya, kesenian tradisional tidak hanya berfungsi sebagai sarana hiburan semata, melainkan juga memiliki fungsi sosial, kultural, serta fungsi spiritual. Keadaan ini pula yang kini tengah dihadapi oleh kebudayaankebudayaan lokal, khususnya keseniankesenian tradisional.

Salah satu jenis kesenian tradisional yang fungsi dan keberadaannya kini sudah mulai tergeser adalah kesenian wayang golek. Wayang golek adalah salah satu jenis kesenian Sunda yang termasuk ke dalam jenis seni pertunjukan. Pada masanya dulu, kesenian wayang golek sempat "berjaya", dalam arti menjadi satu-satunya sarana hiburan masyarakat, yang mampu memenuhi peran dan fungsi-fungsinya di dalam masyarakat. Selain sebagai sarana hiburan yang sangat digemari oleh masyarakat, wayang golek pun berfungsi sebagai sarana penyebaran Islam, serta media informasi yang cukup efektif. Akan tetapi seiring dengan perkembangan zaman, eksistensi kesenian wayang golek pun mengalami perubahan. Keberadaannya kini tidaklah sehebat dan setegar dulu lagi. Ia kini mulai ditinggalkan oleh para pendukungnya. Dengan kata lain, keberadaan kesenian wayang golek saat ini dalam keadaan kritis, jangankan untuk berkembang, untuk bertahan pun sangatlah sulit. Inilah permasalahan yang tengah dihadapi oleh kesenian wayang golek.

Kendatipun keberadaan kesenian wayang golek sebagai seni pertunjukan kini telah mulai tersisihkan oleh jenisjenis kesenian modern, akan tetapi wayang goleknya itu sendiri masih dapat diberdayakan. Kreatifitas para pengrajin wayang golek di Kota Bogor tidak pernah surut dengan semakin langkanya 
pertunjukan wayang golek. Perkembangan aktifitas kepariwisataan telah mampu menciptakan peluang baru bagi pemasaran produk kerajinan wayang golek. Wayang golek yang semula diproduksi untuk bahan pertunjukan kesenian wayang golek, kini diproduksi juga sebagai barang cenderamata.

Fenomena ini menunjukkan adanya pergeseran fungsi wayang golek yang semula sebagai alat kesenian, kini bergeser fungsinya sebagai barang cenderamata. Fenomena inilah yang melatarbelakangi dilakukannya penelitian tentang "Perubahan Fungsi Wayang Golek" di Kota Bogor.

Penelitian ini dimaksudkan sebagai salah satu upaya untuk melestarikan sekaligus mengangkat dan memberdayakan produk wayang golek yang dibuat oleh pengrajin wayang golek di Kota Bogor.

\section{B. Hasil dan Bahasan}

\section{Kota Bogor Selayang Pandang}

\section{Keadaan Alam Kota Bogor}

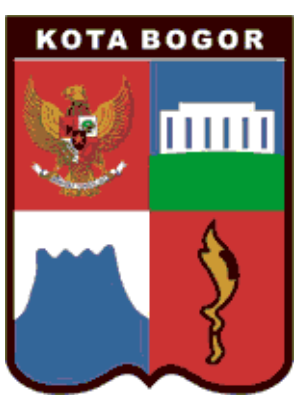

Kota Bogor adalah salalah satu daerah administrasi pemerintahan tingkat II di wilayah Pemerintahan Provinsi Jawa Barat. Posisi Kota Bogor terletak di tengahtengah Kabupaten

Bogor. Jaraknya dari Ibukota Provinsi Jawa Barat sekitar $80 \mathrm{~km}$ ke arah Barat, dan sekitar $40 \mathrm{~km}$ ke arah Selatan dari DKI Jakarta. Kedudukan geografis Kota Bogor di tengah-tengah wilayah Kabupaten Bogor serta lokasinya yang sangat dekat dengan Ibukota Negara, menjadikan Kota Bogor sebagai daerah penyangga ibukota.
Kawasan Bogor dikenal dengan keindahan dan kesejukan alamnya yang indah dan asri. Elevasi Kota Bogor yang terletak pada ketinggian 190 sampai 330 meter dari permukaan laut, menjadikan kawasan Kota Bogor sebagai daerah yang beriklim sejuk. Suhu udara di Kota Bogor berkisar antara $21,8^{0}-30,4^{0} \mathrm{C}$ dengan suhu rata-rata setiap bulan $26^{0} \mathrm{C}$.

Kota Bogor yang memiliki areal seluas $11.650 \mathrm{Ha}$, memiliki batas-batas sebagai berikut: di sebelah utara berbatasan dengan Kecamatan Kemang, Bojong Gede, dan Kecamatan Sukaraja, Kabupaten Bogor. Di sebelah Timur berbatasan dengan Kecamatan Sukaraja, dan Kecamatan Ciawi, Kabupaten Bogor. Di sebelah Barat berbatasan dengan Kecamatan Darmaga, dan Kecamatan Ciomas, Kabupaten Bogor. Di sebelah Selatan berbatasan dengan Kecamatan Cijeruk, dan Kecamatan Caringin, Kabupaten Bogor.

Dalam tata administrasi pemerintahan, Kota Bogor terbagi ke dalam 6 kecamatan dan 68 kelurahan, 210 dusun, $623 \mathrm{RW}$, dan $2.712 \mathrm{RT}$. Jumlah penduduk Kota Bogor menurut data tahun 2004 adalah sebanyak 745.666 jiwa.

\section{Gambaran Kepariwisataan Kota Bogor}

Kota Bogor merupakan daerah yang sangat potensial dan strategis bagi perkembangan sektor ekonomi dan jasa, serta pusat kegiatan nasional untuk industri, perdagangan, transportasi, komunikasi, dan pariwisata. Dalam hal sektor kepariwisataan, Kota Bogor memiliki potensi yang cukup kaya dan sangat beragam. Kota Bogor memiliki obyek-obyek wisata alam, wisata budaya, wisata sejarah, maupun wisata kuliner yang sangat menarik dan dapat dijadikan sumber Pendapatan Asli Daerah (PAD). Obyek-obyek wisata yang ada di Kota Bogor, dapat dikelompokkan ke dalam: 
a. Wisata Budaya/Sejarah;

Di Kota Bogor terdapat banyak obyek wisata budaya dan sejarah, antara lain:

- Istana Kepresidenan Bogor, didirikan tahun 1745 oleh Gubernur Jenderal Hindia Belanda yang bernama Gustaf Willem van Inhof. Istana ini memiliki areal seluas $24 \mathrm{Ha}$, di dalamnya terdapat 219 buah patung keramik/perunggu. Pada mulanya istana ini didirikan sebagai tempat peristirahatan yang diberi nama Buitenzorg. Pada tahun 1950 statusnya berubah menjadi Istana Kepresidenan Republik Indonesia.

- Museum Perjuangan; didirikan tahun 1957 sebagai tempat penyimpanan macam-macam senapan yang digunakan para pejuang kemerdekaan, dan senjata-senjata hasil rampasan dari tentara Jepang dan Inggris. Museum ini dilengkapi dengan diorama perjuangan di daerah Bogor dan sekitarnya.

- Museum Peta; didirikan tahun 1996 oleh Yayasan Perjuangan Tanah Air. Di dalamnya memuat 14 diorama, sebagai salah satu bentuk gambaran perjalanan proses pergerakan kebangsaan.

- Batutulis; prasasti ini dibuat oleh raja Pajajaran Raja Surawisesa (15211535). Tempat di mana prasasti ini berada merupakan tempat untuk melakukan upacara penobatan raja-raja Pajajaran. Prasasti ini bertuliskan huruf Kawi, berbahasa Jawa Kuno.

Masih banyak lagi obyek-obyek wisata budaya dan sejarah yang terdapat di wilayah Kota Bogor yang dapat menarik para wisatawan, baik asing maupun domestik. Tentunya ini akan berpengaruh terhadap Pendapatan Asli Daerah Kota Bogor. b. b. Wisata Ilmu Pengetahuan

Di wilayah Kota Bogor banyak terdapat tempat-tempat yang di dalamnya menyimpan berbagai peninggalan yang dapat dijadikan sebagai sumber pengkajian dan pengembangan ilmu pengetahuan. Tempat-tempat itu antara lain:

- Kebun Raya Bogor, didirikan pada tahun 1817 atas prakarsa seorang akhli botani, yang bernama Prof. Dr. Reinwadt. Kebun Raya ini memiliki areal seluas $87 \mathrm{Ha}$. Koleksi yang terdapat di Kebun Raya Bogor terdiri atas 20.000 tanaman yang tergolong ke dalam 6.000 species. Tidak jauh dari pintu gerbang Kebun Raya, terdapat tugu peringatan yang didirikan oleh Rafles bagi istrinya, Olivia Maria yang meninggal pada tahun 1814

- Museum Etnobotani, didirikan pada tahun 1982 oleh Prof. Dr. B.J. Habibie. Di dalamnya memperagakan pemanfaatan tumbuhan Indonesia dan koleksi fosil kayu, tumbuh-tumbuhan yang dipergunakan untuk obat tradisional. Terdapat pula koleksi daun-daun yang telah diawetkan.

- Museum Zoologi, didirikan pada tahun 1894 dengan nama Nuseum Zoologicum Bogoriensis, yang merupakan bagian dari Lands Plantentuin. Semula bagian ini berfungsi sebagai laboratorium zoologi, tempat menelaah hama pertanian dan perkebunan. Koleksi yang terdapat di dalam museum ini meliputi ribuan spesies binatang mamalia, serangga, reftilia, burung, ikan, dan moluska.

- Museum Tanah, didirikan pada tanggal 29 September 1988, semula adalah Pusat Penelitian Tanah dan Agroklimat yang didirikan pada tahun 1905. Museum ini merupakan tempat penyimpanan model/contoh tanah sebagai koleksi berbagai macam tanah di Indonesia. 


\section{c. Wisata Alam}

Wilayah Bogor dikenal dengan kawasannya yang memiliki pemandangan alam sangat indah. Siapa yang tidak kenal dengan Kawasan Puncak yang berbukit-bukit dengan udaranya yang sejuk dan pemandangan alamnya yang indah dan asri. Kendatipun kawasan puncak ini terdapat di wilayah administratif Pemerintahan Kabupaten Bogor, akan tetapi masih dalam lingkup kawasan wisata Bogor yang memberikan kontribusi sangat berarti bagi pengembangan wisata di wilayah Kota Bogor.

Situ Gede; adalah salah satu dari obyek wisata alam yang terdapat di wilayah Kota Bogor. Situ Gede merupakan satu kawasan yang bernuansa alam pedesaan, dengan danau yang membentang lebar berlatar hutan yang rindang. Sungguh sebuah pemandangan sangat menarik.

Obyek wisata alam lainnya ialah kawasan Rancamaya. Kawasan ini telah dibangun sedemikian rupa sehingga menjadi sebuah kawasan yang memiliki daya tarik keindahan alam, juga dilengkapi dengan sarana dan prasarana olah raga. Kendatipun pada awal masa pembangunannya sempat mengundang protes keras dari para budayawan (Sunda), akan tetapi kini kawasan ini telah menjelma menjadi sebuah kawasan wisata yang banyak menarik minat para wisatawan.

\section{d.Wisata Kuliner}

Dalam hal makanan, Bogor merupakan surga bagi penikmatnya. Berbagai jenis makanan dari yang tradisional sampai makanan yang trendy, semuanya tersedia di Kota Bogor. Berbagai tempat jajan makanan, mulai dari restoran, cafe, sampai warung-warung di pinggir jalan, dan para penjaja makanan, siap memuaskan selera makan pengunjung. Beberapa jenis makanan tradisional yang dapat kita temukan dan nikmati di

Kota Bogor, antara lain:

- Nasi Tutug Oncom, yaitu nasi yang diaduk dengan bumbu kencur dan bawang merah, dicampur dengan oncom hitam bakar yang sudah dihaluskan. Nasi tutug oncom ini biasanya dihidangkan dengan tempe dan tahu goreng, ayam goreng, sambel goang, dan lalapan.

- Gepuk Ayam; yaitu ayam goreng yang "digeprek" (ditumbuk hingga pipih), dimakan bersama nasi timbel.

- Tauge goreng; yaitu tauge yang direbus bersama mie di atas nampan yang dipanaskan dengan bara arang. Tauge goreng ini disajikan bersama tahu goreng, lontong, dan disiram kuah tauco.

\section{e. Souvenir / Cenderamata}

Kreatifitas para seniman di Kota Bogor, telah mampu menciptakan peluang bagi para seniman di samping untuk mengekspresikan rasa seninya, juga untuk bisa mendapatkan keuntungan finansial dari karya seninya. Berbagai jenis karya seni yang kini banyak dijadikan sebagai cenderamata, di antaranya adalah :

- Wayang Golek; wayang golek yang merupakan karya seni ciri khas daerah Priangan, mendapatkan tempat yang cukup layak di kalangan para seniman Kota Bogor. Ini terbukti dengan semakin banyaknya produk wayang golek yang dihasilkan oleh para seniman dan pengrajin di Kota Bogor. Bentuk dan pemberian ornamen, serta hiasan yang indah merupakan salah satu ciri khas kerajinan wayang golek yang dibuat dan diproduksi oleh para pengrajin di wilayah Kota Bogor.

- Keramik; jenis kerajinan yang banyak diminati, yang memberikan efek keindahan bagi suatu ruangan. Ciri khas yang terdapat dalam bentuk, 
warna, serta kualitas produk yang bermutu tinggi, merupakan faktor di mana produk keramik dari Kota Bogor menjadi incaran para wisatawan.

- Bordiran; Perkembangan kerajinan bordiran di Kota Bogor menunjukan kemajuan yang cukup pesat. Ini terbukti dengan tingkat penjualan yang cendreung meningkat dengan pangsa pasar yang cukup jelas, serta didukung oleh produk yang berkualitas dengan ciri khas dan motif yang bernilai seni tinggi, menjadikan produk kerajinan bordir dari Kota Bogor cukup dikenal keberadaannya oleh para wisatawan dari berbagai daerah.

- Goong; adalah bagian dari perangkat musik gamelan. Goong merupakan produk kerajinan unggulan Kota Bogor. Lokasi pembuatan kerajinan goong dan perangkat gamelan lainnya berada di kawasan Pancasan Kelurahan Pasirjaya, Kecmatan Bogor Barat, yang juga merupakan obyek wisata yang culup potensial.

- Kujang; Menurut sejarahnya, kujang merupakan senjata khas warisan dari Kerajaan Sunda. Kini senjata kujang menjadi salah satu simbol Kota Bogor. Senjata kujang sebagai barang hiasan dan cenderamata pun kini sudah banyak diproduksi oleh para pengrajin di Kota Bogor.

\section{Wayang Golek: dari Seni Pertunjukan ke Seni Kriya}

\section{Sekilas Mengenai Sejarah Wayang}

a. Wayang Pada Masa Penyebaran Islam

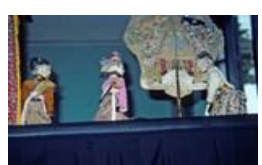

Dalam khasanah budaya Nusantara, wayang sudah menjadi salah satu karya budaya unggulan bangsa. Siapa yang tidak kenal dengan kesenian wayang. Kesenian wayang bukan hanya dikenal di dalam negeri, tetapi sudah mendunia. Di kawasan Nusantara sendiri, kesenian wayang bukan hanya dikenal di Pulau Jawa saja, melainkan juga terdapat pada berbagai kelompok etnik yang ada di Nusantara.

Dalam perjalan sejarahnya, ke-senian wayang telah menapaki perjalanan yang cukup panjang. Mengenai asal-usul wayang khusus di Indonesia, ada beberapa pendapat. Ada yang mengatakan bahwa wayang berasal dari kebudayaan India yang sangat dipengaruhi oleh budaya Hindu. Pendapat lain mengatakan bahwa wayang merupakan hasil kebudayaan asli masyarakat Jawa tanpa ada pengaruh budaya lain. Disebutkan pula oleh beberapa sumber bahwa wayang berasal dari relief candi karena candi memuat cerita wayang, seperti candi Prambanan. Bukti keberadaan wayang dalam perjalanan sejarah di Indonesia tercatat dalam berbagai prasasti, seperti prasasti Tembaga $(840 \mathrm{M})$, prasasti Ugrasena (896 M), dan prasasti Belitung $(907 \mathrm{M})$

Kesenian wayang dalam bentuknya yang asli timbul sebelum kebudayaan Hindu masuk di Indonesia dan mulai berkembang pada jaman Hindu Jawa. Sebagaimana dinyatakan oleh beberapa peneliti sejarah, bahwa sebetulnya budaya wayang merupakan budaya asli Indonesia yang sudah ada jauh sebelum agama Hindu masuk ke Pulau Jawa. Memang, cerita wayang yang populer saat ini merupakan adaptasi cerita dari karya sasra India, yaitu Ramayana dan Mahabharata. Tetapi sudah mengalami adaptasi untuk menyesuaikan dengan falsafah asli Indonesia.

Pada sekitar abad ke-15, agama Hindu/Budha masih menguasai masyarakat di Pulau Jawa. Kala itu pula, agama Islam sudah mulai memasuki daerah kekuasaan kerajaan-kerajaan di Pulau Jawa. Tersebutlah Sunan Kalijaga, salah 
seorang dari Wali Songo, mendatangi pulau Jawa setelah ia kembali dari pelbagai negeri ufuk timur seperti Persia, Turki, Mesir dan Cina. Ia datang ke daerah Pulau Jawa dengan misi menyebarkan agama Islam.

Pada waktu itu, rakyat maupun pembesar Tanah Jawa masih memeluk agama Hindu. Sedikit demi sedikit, Sunan Kalijaga mulai memasukkan faham Islam ke dalam kehidupan spiritual masyarakat Tanah Jawa. Ia pun sangat memahami budaya masyarakat setempat sehingga ketika ia mulai menanamkan ajaran Islam, ia menggunakan media budaya masyarakat setempat. Ia pun mulai memperkenalkan ajaran-ajaran Islam dengan menggunakan media kesenian wayang yang banyak mengisahkan tentang dewa-dewa yang ada dalam faham religi masyarakat setempat, namun ia pun mulai memasukkan ajaran-ajaran Islam dalam media wayang tersebut.

Karena ajaran Hindu sudah sedemikian melekat dalam kehidupan masyarakat kala itu, maka cerita Mahabharata dan Ramayana dari Tanah Hindu dimodifikasi untuk mengajarkan Ketauhidan. Misalkan, dalam cerita Mahabharata para dewa memiliki wewenang yang sangat absolut, sebagai penentu nasib dan takdir yang tidak bisa disanggah, maka para wali membuat objek baru yang posisinya lebih kuat yaitu lewat tokoh Semar. Tokoh Semar tersebut yang karena kesalahannya turun ke bumi untuk mendampingi setiap kejadian dalam babak Bharata Yuddha baik sebagai penengah atau sebagai eksekutor tokoh yang tidak bisa diajak ke dalam kebaikan.

Ajaran Islam lambat laun merasuk ke dalam kehidupan masyarakat di Tanah Jawa. Dalam hal ini terjadi sinkretisasi antara ajaran Hindu yang sudah demikian dalam tertanam dalam jiwa dan perikehidupan masyarakat setempat, dengan ajaran Islam yang disebarkan oleh para wali. Dengan melalui media budaya setempat, dalam hal ini wayang, maka ajaran Islam pun mulai dimengerti dan difahami oleh masyarakat setempat. Dengan teknik pementasan, bahwa, setiap babak pementasan adalah bidang permata atau ibarat tematis filsafat tertentu, dengan menyirat makna tersendiri, yaitu pertikaian antara kebajikan melawan kejahatan yang pada akhirnya dimenangkan oleh kebaikan.

\section{b. Kelahiran Wayang Golek Trimatra}

Di Jawa Barat, tempat berkembangnya wayang pertama kali adalah Cirebon, yaitu pada masa Sunan Gunung Jati (abad ke-15). Jenis wayang yang pertama kali dikenal adalah jenis wayang kulit. Sementara wayang golek mulai dikenal di Cirebon pada awal abad ke-16 dan dikenal dengan nama wayang golek papak atau cepak.

Wayang golek atau disebut "golek" saja, merupakan salah satu jenis tradisi yang hingga sekarang masih tetap bertahan hidup di daerah Sunda. Berbeda dari wayang kulit yang dwimatra, golek adalah salah satu jenis wayang trimatra. Golek memiliki sifat pejal. Ia merupakan boneka tiruan rupa manusia (ikonografi), yang dibuat dari bahan kayu bulat torak untuk mempertunjukkan sebuah lakon.

Kelahiran wayang golek berasal dari ide Dalem Bupati Bandung (Karang Anyar) yang menugaskan Ki Darman, juru wayang kulit asal Tegal yang tinggal di Cibiru, untuk membuat bentuk golek purwa. Awalnya wayang kayu ini masih dipengaruhi bentuk wayang kulit, yaitu gepeng atau dwimatra. Pada perkembangan selanjutnya, tercipta bentuk golek yang semakin membulat atau trimatra seperti yang biasa kita lihat sekarang. Kemudian, pembuatan golek pun menyebar ke seluruh wilayah Jawa Barat seperti Garut, Ciamis, Ciparay, Bogor, 
Karawang, Indramayu, Cirebon, Majalaya, dan sebagainya.

Ada 2 macam wayang golek di daerah Sunda, yaitu wayang golek papak (cepak) atau wayang golek menak, dan wayang golek purwa. Wayang golek yang banyak dikenal orang adalah wayang golek purwa. Sama seperti wayang kulit, pementasan wayang golek purwa menampilkan cerita Ramayana dan Mahabharata.

\section{Wayang Golek sebagai Seni Pertunjukan}

Wayang Golek adalah suatu jenis seni pertunjukan wayang yang terutama sangat populer di wilayah Tanah Pasundan. Pementasan wayang golek pada mulanya hanya dilakukan malam hari, dan memakan waktu semalam penuh. Baru pada abad ke-16, pertunjukan diadakan pula pada siang hari. Wayang yang dipertontonkan memiliki bentuk trimatra, berupa boneka kayu, yang disebut golek. Pertunjukan wayang golek biasanya di tempat terbuka dengan memakai panggung yang ditinggikan (balandongan) sehingga penonton dapat melihat satu arah dan berkonsentrasi pada pertunjukannya.

Sebagaimana alur cerita pewayangan umumnya, dalam pertunjukan wayang golek juga biasanya memiliki lakon-lakon baik galur maupun carangan yang bersumber dari cerita Ramayana dan Mahabharata. Wayang golek adalah sebuah bentuk teater boneka yang dituturkan oleh seorang dalang dalam bahasa Sunda dan diiringi gamelan Sunda laras salendro, yang terdiri atas dua buah saron, sebuah peking, sebuah selentem, satu perangkat bonang, satu perangkat bonang rincik, satu perangkat kenong, sepasang gong (kempul dan goong), ditambah dengan seperangkat kendang (sebuah kendang Indung dan tiga buah kulanter), gambang dan rebab.
Dalam pertunjukan wayang golek, dalang memiliki peranan yang sangat sentral dan menentukan. Dalang mengarahkan pergelaran dan sekaligus berperan selaku: ahli teknik yang menghidupkan wayang, juru ceritera, dan konduktor yang memberi petunjuk kepada para nayaga irama apa yang harus dimainkan. Di samping itu, dalang pun harus menggembirakan penonton selama berjam-jam. Untuk memenuhi tuntutan itu, maka dalang harus mampu menarik penonton dengan guyonan-guyonan yang segar, selain harus menguasai berbagai karakter suara.

Dalam pertunjukan wayang golek, lakon yang biasa dipertunjukan adalah lakon carangan. Hanya kadang-kadang saja dipertunjukan lakon galur. Hal ini seakan menjadi ukuran kepandaian para dalang menciptakan lakon carangan yang bagus dan menarik. Pola pengadegan wayang golek adalah sebagai berikut : 1) Tatalu, dalang dan sinden naik panggung, gending jejer/kawit, murwa, nyandra suluk/kakawen, dan biantara; 2) Babak unjal, paseban, dan bebegalan; 3) Nagara sejen; 4) Patepah; 5) Perang gagal; 6) Panakawan/goro-goro; 7) Perang kembang; 8) Perang raket; dan 9) Tutug.

Salah satu fungsi wayang dalam masyarakat Sunda di antaranya adalah untuk "ngaruat", yaitu membersihkan segala sesuatu, baik orang, maupun lingkungan desa dari segala marabahaya. Orang yang harus diruat disebut dengan istilah "sukerta". Orang-orang yang menurut tradisi Sunda harus diruwat (sukerta), antara lain:

- Nunggal (anak tunggal);

- Nanggung bugang (seorang adik yang kakaknya meninggal dunia);

- Suramba (empat orang putra);

- Surambi (empat orang putri);

- Pandawa (lima putra);

- Pandawi (lima putri); 
- Talaga yanggal kausak (seorang putra dihapit putri);

Samudra hapit sindang (seorang putri dihapit dua orang putra), dan sebagainya.

Pada mulanya, wayang golek sering digunakan untuk menamatkan pagelaran wayang kulit untuk menggambarkan perubahan di jagat raya - aluran berangsur dari tahap wujud eksistensi dwimatra ke yang trimatra. Namun rakyat Jawa Barat lebih menggemari wayang golek karena intisari tematiknya lebih mewujud dan duniawi ketimbang wayang kulit yang lebih cenderung bernuansa abstrak.

Wayang golek saat ini lebih dominan sebagai seni pertunjukan rakyat yang memiliki fungsi yang relevan dengan kebutuhan-kebutuhan masyarakat lingkungannya, baik kebutuhan spiritual maupun hiburan semata. Hal demikian dapat kita lihat dari beberapa kegiatan di masyarakat misalnya ketika ada perayaan, baik hajatan (pesta kenduri) dalam rangka khitanan, pernikahan dan lain-lain, serta dalam acara-acara perayaan yang bersifat nasional, seperti agustusan maupun pada acara-acara resmi kenegaraan.

Sejak tahun 1920-an, selama pertunjukan wayang golek diiringi oleh sinden. Popularitas sinden pada masamasa itu sangat tinggi sehingga mengalahkan popularitas dalang wayang golek itu sendiri, terutama ketika zamannya Upit Sarimanah dan Titim Patimah sekitar tahun 1960-an.

Di tengah hingar-bingarnya kesenian-kesenian modern, seorang dalang dituntut untuk bisa memikat khalayak agar tetap tertarik, meminati, dan tidak berpaling dari kesenian wayang golek yang merupakan kesenian tradisional masyarakat Sunda. Tentu saja ini menuntut kepiawaian dan keberaniannya mendobrak atau merekonstruksi pakem atau aturan pewayangan tradisional. Dengan memasukkan nilainilai modernitas, ia dalang berupaya mengkreasi alur cerita, setting, dan jenis wayang kayu. Ini mengindikasikan bahwa wayang golek Sunda tidak anti perubahan. Seni pertunjukan ini terus menyesuaikan dengan perkembangan zaman agar tetap dicintai masyarakatnya.

\section{Wayang Golek Sebagai Cenderamata}

Geliat dunia pariwisata, ternyata membawa dampak positif bagi para pengrajin wayang golek. Di tengah situasi yang sangat tidak menguntungkan bagi keberadaan seni pertunjukan wayang golek, dunia pariwisata telah menciptakan peluang baru yang cukup prospektif bagi para pengrajin wayang golek. Kendatipun wayang golek kini sudah jarang dipesan untuk seni pertunjukan, akan tetapi para pengra-jinnya mendapat pangsa pasar lain, yaitu para turis, baik turis asing maupun turis domestik. Dalam hal ini kreatifitas para pengrajin wayang golek dituntut untuk lebih bisa menarik konsumen. Tidak jarang para konsumen ini bukanlah pengemar pertunjukan wayang, akan tetapi mereka semata-mata hanya menyenangi bentuk dan penampilan wayangnya saja. Mereka pun membeli wayang golek hanya sekedar untuk pajangan sebagai benda bernilai seni, penghias ruangan, atau untuk cenderamata.

Sebagai barang cenderamata, pembuatan wayang golek pun tidak harus terlalu mematuhi pakem-pakem yang terdapat dalam dunia pewayangan. Namun karakter dasar dari setiap wayang tetap dipertahankan. Kelebihannya adalah para pengrajin bisa lebih berimprovisasi, khususnya dalam pewarnaan.

Wayang golek adalah sejenis boneka kayu yang dibuat sedemikian rupa, dengan bagian-bagian, kepala, 
badan, dan tangan. Kepala dan lengan wayang golek dapat dilepaskan Antara kepala, badan, dan lengan dihubungkan oleh sebatang kayu kecil bulat yang lazim disebut tuding atau gagang. Tuding digunakan sebagai pegangan dalang pada saat memainkan golek, yaitu alat untuk menggerakkan bagian tangan golek dan untuk menancapkan golek di atas alas gebok/dudukan golek. Tuding biasanya terbuat dari bambu. Wayang golek lazimnya berpakaian tenunan berwarnawarni, kain beludru, dengan aneka asesoris berupa mute-mute plastik.

Daya tarik wayang golek adalah bentuknya yang tidak monoton, baik bagi konsumen (pembeli) maupun bagi pembuatnya. Wayang golek dirancang sedemikian rupa untuk menarik konsumen dan bagus ketika dipajang di galeri. Sementara pembuat wayang golek termotivasi untuk berkreasi misalnya mereka bebas memberi warna pada berbagai karakter wayang golek yang mereka buat. Ini membuat pengrajin wayang golek bisa memnciptakan aneka tampilan wayang golek, sehingga wayang golek ada yang terlihat antik, natural, maupun yang berwarna emas.

Pembuatan dan Prospek Pengembangan Wayang Golek

\section{Pembuatan Wayang Golek}

Wayang golek adalah sejenis boneka kayu yang dibuat dengan cara diraut dan diukir dengan bagian-bagian, kepala, badan, dan tangan. Kepala, badan, dan lengan wayang golek dapat dilepaskan. Antara kepala, badan, dan lengan dihubungkan oleh sebatang kayu kecil bulat yang lazim disebut gagang. Wayang golek lazimnya berpakaian tenunan berwarna-warni. Gagang ini selain berfungsi untuk menghubungkan bagian kepala, badan, dan tangan, juga berfungsi untuk meletakkan wayang tersebut di atas "gebog" (batang pisang), dengan cara ditancapkan.

Setiap tokoh wayang memiliki sifat dan karakter sendiri-sendiri, yang secara umum dikelompokkan dalam 2 kelompok besar, yaitu tokoh yang berkarakter baik, dan yang berkarakter buruk. Dalam setiap pertunjukan wayang, kedua kelompok tokoh yang berlainan karakter ini senantiasa dihadapkan sebagai lawan satu sama lain. Sebagaimana diketahui, bahwa dalam dunia pedalangan terdapat dua sember cerita pewayangan, yaitu yang mengambil dari perang Bahabharata, yang menghadapkan tokoh-tokoh dari Negara Amarta dengan tokoh-tokoh Negara Astina yang dihadapkan sebagai dua kelompok yang berlawanan. Tokohtokoh Negara Amarta dengan tokoh Pandawanya dikelompokkan dalam golongan protagonis, sedangkan tokohtokoh Negara Astina dengan tokoh-tokoh Kurawa-nya digolongkan sebagai kelompok antagonis. Tokoh yang baik (protagonis) selalu tampil dari sisi sebelah kanan, sedangkan lawannya (antagonis), sebelah kiri.

Menurut penuturan seorang informan, terdapat kurang lebih 120 karakter tokoh wayang, yang tergolong ke dalam karakter protagonis dan antagonis. Secara visual, karakter masing-masing tokoh dalam pewayangan ini digambarkan melalui pembedaan bentuk dan warna kulit muka. Secara umum, karakteristik para tokoh ini digolongkan ke dalam 4 golongan utama, yaitu:

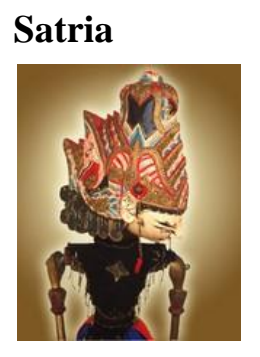

Bentuk tubuh golek golongan satria ini menggambarkan keluwesan, ketenangan dan kelemahlembutan, dengan tetap tidak menghilangkan unsur kegagahan dan 
kecerdasannya. Golongan ini memiliki bentuk mata sipit, alis tipis, dan hidung cenderung kecil dan tidak memiliki kumis. Tokohnya seperti Rama, Samiaji, Nakula, Sadewa.

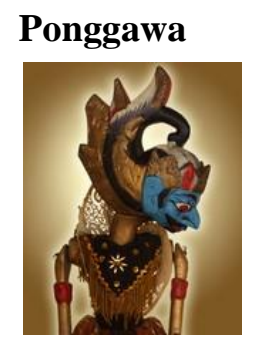

Golongan golek ini digambarkan sebagai tentara yang ditampilkan dengan bentuk tubuh yang tegap, tegas, dengan mata besar, alis tebal, berkumis, hidung mancung. Tokoh-tokohnya antara lain Gatotkaca, Bima, Duryudana.

\section{Buta}

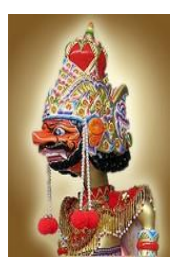

Buta atau disebut juga raksasa memiliki bentuk tubuh tinggi besar, mata melotot, alis tebal, hidung besar dan bertaring atas bawah. Tokoh golongan ini yang terkenal adalah

Rahwana.

\section{Panakawan}

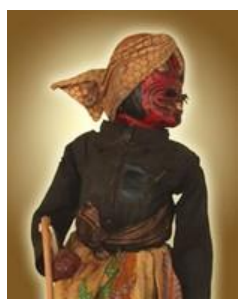

Golongan golek ini digambarkan sebagai tokoh yang kocak dan jenaka. Banyak golek ciptaan baru yang digolongkan dalam go-lek panakawan.

Dilihat dari bentuknya, apabila raut wajah atau muka tokoh wayang dengan sorot mata yang halus serta kepala menunduk, pertanda bahwa wayang tersebut termasuk ke dalam golongan tokoh yang baik. Sedangkan bila bentuk matanya melotot dengan pandangan yang kasar dan lurus ke depan, menandakan tokoh jahat dalam versi pewayangan.

\section{Bahan}

Bahan utama untuk membuat wayang golek adalah kayu. Jenis kayu yang biasa dipakai adalah kayu lame atau kayu mahoni yang didapat dari hutan di sekitar Bogor. Dengan peralatan yang sangat sederhana yaitu peralatan tradisional yang digunakan seperti bedog, gergaji, kampak besar, kampak kecil, pisau raut (pisau ukir), dan lain sebagainya, selanjutnya dapat menghasilkan wayang dengan bentuk yang sempurna untuk seterusnya di jual kepada konsumen.

Menurut penuturan seorang informan, konsumen wayang produknya banyak yang dari luar negeri. Oleh sebab itu, ia lebih banyak menggunakan kayu lame, karena kayu lame sudah terbukti ketahanannya dan tidak mudah pecah walaupun di daerah yang memiliki 4 musim. Ada juga pengrajin yang memakai bahan dari kayu albasia, karena jenis kayu ini ringan, mudah dibentuk atau dipahat, serta tahan lama terhadap cuaca.

Bahan lain yang diperlukan untuk membuat wayang adalah cat pewarna. Pewarna yang digunakan adalah cat kayu yang berwarna cerah dan mudah kering. Bahan pewarna yang kini banyak digunakan adalah cat duko (cat untuk mobil). Cat duko lebih menguntungkan dari segi penampilan golek sebab warna golek menjadi lebih cerah. Selain itu, cat duko lebih mudah kering dibandingkan cat kayu.

Bahan lainnya adalah bambu, yang digunakan untuk membuat tuding. Tuding digunakan sebagai pegangan dalang pada saat memainkan golek, yaitu alat untuk menggerakkan bagian tangan golek dan untuk menancapkan golek di atas alas gebok/dudukan golek.

Bahan untuk pakaiannya dibuat dari kain beludru berwarna-warni, dipadu dengan asesoris dari mute-mute plastik yang berkilat. 


\section{Proses Pembuatan}

Wayang golek dibentuk dengan cara diraut dan diukir. Setelah itu didempul. Sebelum diwarnai, diberi arsiran dulu untuk menentukan bagian mana akan diberi warna apa. Sementara pada bagian hiasannya, dibuat dengan cara dipulas.

Proses awal pembuatan wayang adalah membuat gambar wajah terlebih dahulu secara detaial. Setelah itu kayu yang telah dibentuk, dihaluskan dengan amplas, lalu mulai diukir menggunakan pisau ukir dengan sangat teliti untuk membuat bagian kepala. Selanjutnya dilakukan proses pengecatan. Sambil menunggu pengeringan, maka dilanjutkan dengan membuat bagian badan dan tangan. Untuk pembuatan tangan harus diukur terlebih dahulu. Setelah itu dilanjutkan dengan membuat bagian mahkota di kepala. Proses pengeringan harus dilakukan pada cuaca yang tepat, karena proses pengeringan tidak boleh terlalu panas sehingga cat tidak mengelupas.

Sementara itu, untuk pakaiannya biasanya digunakan kain tenun berwarnawarni atau kain beludru yang dibuat dengan cara dijahit. Pakaian ini kemudian diberi manik-manik dari bahan mute plastik yang mengkilat.

Membuat wayang golek, tidaklah mudah. Untuk membuat wayang yang detailnya tidak terlalu rumit para pengrajin ini dapat membuat/ menghasilkan 3 kepala wayang perhari, sedangkan untuk wayang dengan detail yang rumit bisa membutuhkan waktu hingga 2 hari per satu kepala dan untuk menyelesaikan satu buah wayang dengan segala bentuk dan komplit dengan asesorisnya dibutuhkan waktu kurang lebih 3 hari.

\section{Pemasaran}

Dalam hal pemasaran wayang golek terdapat peluang-peluang yang cukup prospektif. Menurut penuturan seorang pengrajin, tanpa melakukan promosi pun wayang golek masih banyak digemari oleh masyarakat Indonesia maupun turis asing. Beberapa negara asal turis asing yang pernah berkunjung dan membeli wayang golek produk Kota Bogor adalah dari Polandia, Belgia, Jepang, dan Belanda. Belgia adalah negara yang baru saja memesan wayang sebanyak 40 buah guna dibawa ke negaranya sebagai souvenir. Orang Indonesia yang akan pergi ke luar negeri pun banyak yang membawa wayang golek sebagai tanda cideramata atau souvenir atau buah tangan bagi negara yang dikunjungi. Maka secara tidak langsung wayang ini telah dikenal sampai ke berbagai negara.

Upaya-upaya promosi telah memberikan manfaat yang besar. Pada umumnya konsumen datang langsung ke tempat pembuatan wayang atau padepokan. Mereka mengetahui tempat pembuatan wayang hasil dari promosi yang dilakukan oleh para pengusaha dan pengrajin melalui pameran-pameran. Di samping itu sering pula datang pesanan dari berbagai instansi dan hotel seperti, Hotel Indonesia yang memesan wayang hingga 200 buah, dan dari Dinas Pariwisata Serang memesan wayang sebanyak 80 buah.

Wayang golek yang diproduksi oleh para pengrajin di Kota Bogor sudah menyebar ke luar negeri, seperti Belanda, Prancis dan Amerika. Jenis wayang golek yang banyak digemari oleh para turis asing adalah tokoh Rama dan Sinta. Harga jual satu buah wayang golek untuk turis asing adalah sekitar 30 Euro, sedangkan untuk pembeli lokal dengan ukuran $40 \mathrm{~cm}$ dijual seharga Rp. 250.000,- dan untuk ukuran $60 \mathrm{~cm}$ dijual 
dengan harga Rp. 400.000,-, Yang membedakan harga wayang yaitu dari ukuran besar kecilnya bentuk wayang, bukan dari kesulitan dalam membuat wayang.

Kelebihan dari pengrajin wayang golek yang ada di Kota Bogor ini adalah tanpa adanya pendidikan khusus ataupun tanpa kursus, semua bisa dikerjakan dengan baik. Semua itu karena kemauan, memiliki jiwa seni yang tinggi, juga karena ketekunan dan kecintaannya terhadap seni pertunjukan wayang golek.

\section{Prospek Pengembangan}

Perkembangan dunia modern, di satu sisi memberikan dampak negatif bagi keberadaan wayang golek. Dunia hiburan, kini lebih didominasi oleh jenisjenis kesenian modern, sedangkan pertunjukan kesenian tradisional, terma-suk wayang golek, sangat langka. Akan tetapi di sisi lain, perkembangan dunia modern pun telah membuka peluang yang luas kepada para seniman wayang golek untuk berkreasi lebih jauh. Dari segi substansi, lahir lakon-lakon galur dan carangan yang semuanya bersumber dari Cerita Mahabharata dan Ramayana. Dari segi penampilannya, bentuk wayang pun mengalami modifikasi-modifikasi. Bahkan di era modern sekarang ini, pertunjukan wayang golek cukup sarat dengan tampilan-tampilan yang memanfaatkan kemajuan teknologi.

Ini membuktikan, bahwa kesenian wayang tidak anti perubahan. Maka ungkapan "miindung ka waktu, mibapa ka jaman" adalah justifikasi yang tidak mengada-ada untuk menyebut epistemologi praksis gaya dalang-dalang modern untuk tetap mempertahankan eksistensi kesenian wayang golek di tengah-tengah arus tuntutan zaman. Demikian pula faktor wayangnya yang berupa boneka kayu, terus menerus direkayasa sedemikian rupa dengan menggunakan teknik-teknik modern, sehingga boneka kayu itu nampak lebih hidup dan lebih menarik. Sejalan dengan tuntutan itu, maka teknologi pembuatan wayang golek pun semakin maju.

Frekuensi pertunjukan wayang golek yang mulai surut tidak serta merta turut menyurutkan kreatifitas para seniman dan pengrajin wayang golek untuk terus berkreasi memproduksi wayang golek. Ada pangsa lain yang memungkinkan wayang golek tetap eksis, kendatipun sebagai seni pertunjukan ia telah mulai berkurang. Perkembangan dunia pariwisata ternyata telah membuka peluang yang cukup luas bagi pemasaran kerajinan wayang golek. Kini, pembuatan wayang golek dengan kekhasannya lebih banyak diproduksi untuk bahan cenderamata dari tanah Sunda bagi para turis, ketimbang sebagai alat seni pertunjukan.

Geliat dunia pariwisata, yang sempat terpuruk ketika maraknya aksi bom dan terorisme, telah membawa harapan baru bagi pengembangan seni wayang golek. Arus kedatangan wisatawan Nusantara maupun Mancanegara ke Kota Bogor, telah memberikan dampak positif bagi pemasaran wayang golek. Para pengrajin dan pengusaha wayang golek pun kini memiliki harapan baru untuk tetap eksis dan berkembang, kendati pun seni pertunjukan wayang golek sudah mulai langka.

\section{Penutup}

Kesenian wayang golek yang telah menjadi ciri dan jatidiri orang Sunda telah melewati perjalanan sejarah yang cukup panjang. Pada awal kelahirannya, wayang golek adalah sebagai sebuah bentuk seni pertunjukan yang memiliki beberapa fungsi, antara lain: fungsi religius, fungsi hiburan, fungsi sosial, dan fungsi penyampaian informasi. 
Pada masa penyebaran Islam, kesenian wayang dijadikan sebagai media syiar Islam yang telah terbukti keampuhannya. Melalui media wayang, ajaran-ajaran Islam lebih mudah diterima dan difahami oleh masyarakat di Pulau Jawa yang pada masa itu menganut Agama Hindu. Dalam perkembangan berikutnya, wayang golek juga lazim dipentaskan dalam perayaan khusus seperti khitanan, perkawinan, perayaan karawitan, hari-hari besar, dan penyambutan tamu-tamu Negara. Wayang golek saat ini lebih dominan sebagai seni pertunjukan rakyat, yang memiliki fungsi yang relevan dengan kebutuhan masyarakat lingkungannya, baik kebutuhan spiritual maupun material.

Perkembangan zaman telah memunculkan tuntutan-tuntutan baru bagi umat manusia, termasuk dalam hal pemenuhan akan hiburan. Derasnya arus jenis-jenis kesenian modern yang kini mendominasi dunia hiburan, telah menyisihkan keberadaan seni-seni tradisional. Kesenian-kesnian tradisional, seperti wayang golek pun ikut tersisih dan semakin langka dipertunjukkan.

Namun demikian, ada pangsa lain yang memungkinkan kesenian wayang golek tetap eksis, yakni melalui industri pariwisata. Kesenian wayang golek pun akhirnya mengalami pergeseran fungsi, yang semula sebagai seni pertunjukan, kini lebih berfungsi sebagai cenderamata.

Kendatipun kesenian wayang golek tetap bisa eksis di tengah-tengah arus perubahan zaman, akan tetapi itu pun tidak berarti tanpa kendala. Permasalahan yang muncul sekarang ini adalah rendahnya minat masyarakat untuk menjadi pengrajin wayang golek. Ini mengakibatkan langkanya pembuat wayang golek, padahal peminat dan permintaan terhadap wayang golek masih tinggi, terutama para wisatawan asing. Di samping itu orang dalam negeri yang akan pergi ke luar negeri pun sering membawa wayang golek sebagai cinderamata. Keadaan seperti ini seringkali menimbulkan kesulitan bagi sanggar-sanggar atau padepokanpadepokan yang memperoduksi wayang golek, maupun para pengusaha kerajinan untuk memenuhi pesanan para klien.

Mengacu pada permasalahan di atas, berikut dikemukakan beberapa rekomendasi:

1. Perlu adanya penginventarisasian para pengrajin dan seniman wayang golek, khususnya di wilayah Kota Bogor.

2. Perlu adanya bimbingan dan penyuluhan manajerial bagi para pengrajin dan pengusaha wayang golek.

3. Perlu diciptakan even-even khusus yang bisa mempromosikan kesenian wayang golek, baik dalam rangka pertunjukan kesenian, maupun pameran-pameran.

\section{DAFTAR PUSTAKA}

Kota Bogor. Dinas Informasi Kepariwisataan dan Kebudayaan. tth. Bogor Travel Guide.

Kurnia, Ganjar. 2003.

Deskripsi Kesenian Jawa Barat. Bandung: Dinas Kebudayaan \& Pariwisata Jawa Barat.

Suryana, Jajang. 2002.

Wayang Golek Sunda, Kajian Estetika Rupa Tokoh Golek. Bandung: Kiblat Buku Utama.

Zeitlin, Irving. 1998.

Memahami Kembali Sosiologi. Yogyakarta: UGM Press. 
